\title{
Medical Malpractice Arbitration Act: Michigan's Experience with Arbitration
}

Mary Bedikian*

\begin{abstract}
In the 1970's, Michigan and other states were confronted with a medical malpractice crisis of astronomical proportions. The escalating number of medical malpractice lawsuits and concomitant increase in malpractice premiums for health care providers fostered a divisive climate among doctors, lawyers and patients. In response to this crisis, the Michigan legislature enacted the Medical Malpractice Arbitration Act. The Act establishes a process whereby patients may agree to arbitrate any claims rather than pursue them through the courts.

Part II of this Article discusses the historical evolution of arbitration as a precursor to its establishment as a resolution modality for health care disputes. Part III describes the statutory framework of the Michigan Medical Malpractice Arbitration Act. Part IV discusses the contractual and constitutional challenges to the arbitration statute and their resolution in Morris v. Metriyakool.

As the law respecting arbitration becomes less vulnerable to judicial perforation, this Author suggests that other jurisdictions treat the Michigan Medical Arbitration Program as an archetype, susceptible to replication.
\end{abstract}

\section{INTRODUCTION}

In 1975, the Michigan legislature enacted the Medical Malpractice Arbitration Act. ${ }^{1}$ The purpose of the Act was to ameliorate, if not effectively eliminate, the medical industry's malpractice crisis. ${ }^{2}$ Members of

\footnotetext{
* Michigan Regional Director, American Arbitration Asociation; B. A. 1971, M.A. 1975, Wayne State University; J.D. 1980, Detroit College of Law.

11975 Mich. Pub. Acts Nos. 140, 141 (codified at Mich. Comp. Laws $\$$ 500.305 1-.3062, $600.5033-.5065(1979))$.

${ }^{2}$ See generally House Comm, on Interstate and Foreign Commerce, 94th Conc., 1 st Sess., An Overview of Medical Malpractice 30 (Comm. Print 1975); U.S. Dep't of Health,
} 
influential interest groups helped sponsor this legislation, including the UAW, the Michigan Catholic Conference, the American Federation of Labor, the Michigan Chamber of Commerce, the Michigan Hospital Association, the Physicians' Crisis Committee, the Michigan State Medical Society and the Michigan State Bar. ${ }^{3}$

Since its adoption and implementation, this arbitration scheme has divided courts, commentators and members of the medical and legal professions regarding its feasibility. ${ }^{4}$ Two countervailing philosophical perspectives have occupied the forefront of debate. One viewpoint contends that arbitration of medical malpractice claims is not cost effective and has an imperceptible effect on the reduction of malpractice insurance premiums. The proponents of this viewpoint maintain further that the arbitration statute deprives malpractice victims of a full and fair hearing, thus diluting the due process rights to which all plaintiffs are entitled. ${ }^{5}$ The other viewpoint contends that arbitration provides a more expeditious and economical method for the resolution of malpractice claims. Built-in procedural safeguards, most notably the fact that arbitration is optional for the patient, afford adequate due process protection. ${ }^{6}$

This Article explores the historical framework of arbitration. It will describe the statutory structure of the process, and assess the various constitutional and contractual challenges that have been raised. Finally, the Article discusses an evaluation of Michigan's experience under the Medical Malpractice Arbitration Act.

\section{HISTORICAL ANTECEDENTS OF THE MICHIGAN MEDICAL ARBITRATION ACT}

In the 1970's, the health care profession suffered from a malpractice crisis of incomparable proportions. ${ }^{7}$ Malpractice insurance premiums were

Education \& Welfare, Medical Malpractice: Report of the Secretary's Commission of Medical Mal.practice 4 (1973); Lerner, The Medical Malpractice Crisis: Response v. Reaction, Am. Arb. Ass'n Wide World Arb. 140 (1978); Note, Medical Malpractice Arbitration: Time for a Model Act, 33 Rutgers L. REv. 454 (1981).

${ }^{3}$ See generally American Arb. Ass'n, Michigan Medical Arbitration Program, BulleTIN No. 1 (1980).

${ }^{4}$ See, e.g., Ducastel, Medical Malpractice: Fact or Fiction?, 60 Mich. Bar J. 940 (1981); Mengel, The Constitutional and Contractual Challenges to Michigan's Medical Malpractice Aribitration Act, 59 J. Urb. Laws 319 (1982); Sidel, Malpractice Reform in Michigan, 1976 Det. C.L. Rev. 235; Note, The Michigan Malpractice Acts Requirement of a Physician on the Panel Violates the Due Process Rights to a Fair and Impartial Tribunal, 28 WAYNe L. Rev. 1843 (1982).

5 See Schoonmaker, The Medical Malpractice Arbitration Program in Michigan, Ins. L.J. 370 (1977); Note, supra note 4; see also, infra notes 33-56 and accompanying text.

${ }^{6}$ See Morris v. Metriyakool 418 Mich. 423, 344 N.W.2d 736(1984); see also infra notes 34-56 and accompanying text.

${ }^{7}$ Increasing numbers of malpractice verdicts against doctors, hospitals and other health service providers resulted in rapidly escalating malpractice insurance costs and 
escalating at an astounding rate, while concomitantly, the availability of malpractice insurance was shrinking. ${ }^{8}$ In Michigan, this situation was exacerbated by the fact that malpractice insurance was not being offered to new or incoming doctors by the companies who had been providing nearly ninety-three percent of the malpractice insurance policies. ${ }^{9}$ In an effort to develop a more supportive atmosphere for health care practitioners, numerous states began to contemplate alternatives to stave off or curtail the expansion of the malpractice crisis. Most states responded by enacting some type of medical malpractice reform legislation; ${ }^{10}$ many of these responses included some form of arbitration mechanism. ${ }^{11}$

Arbitration has long been accepted as an effective and non-combative form of dispute resolution. It was well-institutionalized even before the development of English common law. Scholars have traced its origin to the Athenian culture in 700 B.C. ${ }^{12}$ The United States Supreme Court examined the viability of arbitration as a form of dispute resolution in the Steelworkers Trilogy of $1960 .{ }^{13}$ The Court addressed the importance of pre-

a general deterioration of the medical profession's liability insurance marketplace. Several insurers reduced the scope of available malpractice liability coverage, and in some regions physicians experienced difficulty in obtainıng insurance at any price.

Note, supra note 2, at 454 .

${ }^{8}$ The crisis elicited a national inquiry. In 1971, the Department of Health, Education \& Welfare established a Medical Malpractice Commission. The Commission sponsored a 1.5 million dollar research project and conducted public hearings. The Commission concluded:

The total number of claims paid does not appear to be as important a factor in the overall problem as does the number that give rise to large settlements or awards. These relatively few claims (the 6.1 percent above $\$ 40,000$ ) appear to be the ones that most alarm health-care providers. [M]ore than half of the claimants who receive payment get less than $\$ 3,000$, the other half receive more. Less than one out of every 1,000 claims paid is for $\$ 1$ million or more, and there are probably not more than seven such payments each year. There is little doubt that the number of large awards or settlements has been increasing dramatically within the recent past.

U.S. Dep't of Health, Education \& Welfare, supra note 2, at 10.

${ }^{9}$ Mengel, supra note 4, at 319 (citing H.R. Cong. Res. 14, 78th Leg., 3d Sess., 1975 J. House of Representatives State of Mich. 107; H.R. Res. 15, 78th Leg., 4th Sess., 1975 J. OF THE STATE OF Mich, 127-28).

${ }^{10}$ Ladimer, Medical Malpractice Claims, in Arbitration: Commercial Disputes, Insurance, and Tort Claims 301-02 (A. Widiss ed, 1979).

11 See Ala. Code \& 6-5-485 (1975); Alaska Stat. \$ 09.55.535 (1983); Cal. Civ. Proc. Code $\$ 1295$ (West 1982); GA. Code $\$ \$ 9-9-110$ to -133 (1982); Ill. AnN. Stat, ch. 10, $\S \S 201-214$ (Smith-Hurd Supp. 1984): La. Rev. Stat. Ann. §§ 9:4230-:4236 (1983); Мich. Comp. Laws \$§ 600.5040-.5065 (1979); N.D. Cent. Code \$§ 32-29-01 to - 10 (1976); Ohto Rev. Code Ann. \$§ 27.11.21-.24 (Page 1981); S.D. Codified Laws Ann. \$\$ 21-25B-1 to -3 (1979); Vt. Stat. Ann. tit. 12, \& 7002 (Supp. 1984); VA. Code \& 8.01-581.12 (1984).

${ }^{12}$ C. Wooley, The Sumerians 93-94 (1929).

13 The trilogy consisted of three steel workers union disputes: United Steelworkers of America v. American Mfg. Corp., 363 U.S. 564 (1960); United Steelworkers of America v. Warrior and Gulf Navigation Co., 363 U.S. 574 (1960); United Steelworkers of America v. Enterprise Wheel and Car Corp., 363 U.S. 593 (1960). 
serving an extra-judicial mechanism which fundamentally served the interests of the private industrial sector.

In Alexander $v$. Gardner-Denver Co., ${ }^{14}$ the Supreme Court reaffirmed the importance of the arbitration process. In this landmark decision, the Court held that an employee's statutory right to trial de novo under Title VII of the Civil Rights Act of 1964 is not foreclosed by a prior submission of his claim to final and binding arbitration pursuant to a nondiscrimination clause in a collective bargaining agreement. ${ }^{15}$

While many arbitration opponents have construed Gardner-Denver as a decision which restricts an arbitrator's authority, the effect on the arbitration process was minimal. The Court's emphasis was not on whether arbitration would occupy a pivotal position in the dispute resolution arena, but rather on the process by which individual employee rights should be guarded. The Court merely separated statutory rights from collective bargaining or contractual rights. Thus, Gardner-Denver did not condemn the arbitral process. Rather, it suggested that arbitration may not be appropriate for the resolution of a discrimination claim if the arbitrator's competence is limited to an interpretation of the collective bargaining agreement.

The Court addressed several critical issues. The principal issue was whether arbitration could be compelled by a party to a contract. The Court held that while the determination of arbitrability lies exclusively within the province of the courts, the courts should not intercede unless the arbitration clause is not susceptible to an interpretation that covers the dispute. The courts use this as a pretext to invoke jurisdiction. All doubts relating to arbitrability must be resolved in favor of the arbitration process. Warrior and Gulf Navigation Co., 363 U.S. at 582-83.

The second issue concerned the scope of judicial review. The Court held that the interpretation of the agreements was clearly for the arbitrator to decide. Courts were not empowered to substitute their own judgment for that of the arbitrator. The Court's opinion contained this significant and much-quoted paragraph:

When an arbitrator is commissioned to interpret and apply the collective bargaining agreement, he is to bring his informed judgment to bear in order to reach a fair solution of a problem. This is especially true when it comes to formulating remedies. There the need is for flexibility in meeting a wide variety of situations. The draftsmen may never have thought of what specific remedy should be awarded to meet a particular contingency. Nevertheless, an arbitrator is confined to interpretation and application of the collective bargaining agreement; he does not sit to dispense his own brand of industrial justice. He may of course look for guidance from many sources, yet his award is legitimate only so long as it draws its essence from the collective bargaining agreement. When the arbitrator's words manifest an infidelity to this obligation, courts have no choice but to refuse enforcement of the awards.

Enterprise Wheel and Car Corp., 363 U.S. at 597 (emphasis added).

Third, the Court discussed the merits of a dispute brought for judicial hearing. The Court observed that it is not for the courts to make excursions into an arbitrator's jurisdiction, and render determinations on the merits of a dispute. No matter the extent that it appears the arbitrator's opinion is improper or incorrect, it cannot be modified unless the arbitrator abused or exceeded his contractual authority. Enterprise Wheel and Car Corp., 363 U.S. at 598-99; see also Note, Arbitration and the Courts, 58 Nw. U.L. Rev. 466 (1963).

14415 U.S. 36 (1974).

15 Id. at 49 . 
The resolution of a discrimination claim must address statutory violations. ${ }^{16}$

The Michigan Supreme Court provided support for arbitration in Michigan in Kaleva-Norman-Dickson School District No. 6 v. Kaleva-NormanDickson School Teachers' Association. ${ }^{17}$ Here, the court held that without an express provision that excluded a particular grievance from arbitration, the contested matter had to proceed to arbitration. ${ }^{18}$ The Court placed the burden on the party requesting judicial relief to establish that the matter in dispute was explicitly not recognizable under the general arbitration clause. ${ }^{19}$

Thus, when faced with the health care crisis in the early 1970's, Michigan considered adopting a unique, comprehensive and more responsive dispute resolution mechanism to counter the professional concerns which the crisis had generated. In 1975, the Michigan legislature enacted the Medical Malpractice Arbitration Act, ${ }^{20}$ establishing voluntary arbitration as an alternative forum for seeking redress in malpractice cases. One of the chief arguments against the adoption of arbitration was that it would reduce the number and size of the awards to patients.

Prior to the passage of this legislation, the Insurance Commission presented a comprehensive report to the Governor. ${ }^{21}$ This report tentatively responded to opponents' concerns that malpractice arbitration would reduce judgment amounts. While the Commissioner's Report suggested that an accurate assessment of whether an arbitration system would reduce the number of sizeable judgments was impossible, the Report recommended that legislation be adopted to permit the establishment of contractual and binding arbitration in medical malpractice cases. ${ }^{22}$

${ }^{16}$ The Court had previously addressed this issue in United Steelworkers of America v. Warrior and Gulf Navigation Co., 363 U.S. 574, $581-82$ (1960), stating:

Arbitral procedures, while well-suited to the resolution of contractual disputes, make arbitration a comparatively inappropriate forum for the final resolution of rights created by Title VII. This conclusion rests first on the special role of the arbitrator, whose task is to effectuate the intent of the parties rather than the requirements of enacted legislation. Where the collective-bargaining agreement conflicts with Title VII, the arbitration must follow the agreement. To be sure, the tension between contractual and statutory objectives may be mitigated where a collective-bargaining agreement contains provisions facially similar to those of Title VII. But other facts may still render arbitral processes comparatively inferior to judicial processes in the protection of Title VII rights. Among these is the fact that the specialized competence of arbitrators pertains primarily to the law of the shop, not the law of the land.

17393 Mich. 583, 227 N.W.2d 500 (1975).

${ }^{18}$ Id. at 591,227 N.W.2d at 503-04.

${ }^{19} \mathrm{Id}$. at 595,227 N.W.2d at 506.

${ }^{20} 1975$ Mich. Pub. Acts Nos. 140, 141 (codified at Mıсн. Comp. Laws $\S \S 500.3051-.3062$, 600.5033-.5065 (1979)).

21 Demlow \& Dively, Medical Malpractice in Michigan 6 (Mich., Feb. 18, 1975).

22 Id. at 21 . 
The Insurance Commission furnished an additional report to the Governor immediately prior to the passage of the Act which set forth the goals of the legislation. The legislation sought to reduce the costs of settling medical malpractice disputes; to promote equitable settlements and avoid unnecessary appeals; to expedite the resolution of malpractice claims; and to offer a patient freedom of choice by instituting arbitration as a voluntary alternative to litigation. ${ }^{23}$ The failure to establish a definitive statistical correlation between arbitration and reduced malpractice verdicts lessened the impact of such concerns in the ultimate design and establishment of the arbitration scheme.

\section{THE STATUTORY FRAMEWORK OF THE MICHIGAN MEDICAL MALPRACTICE ARBITRATION ACT}

In 1976, the Michigan Medical Malpractice Arbitration Act (the Act) ${ }^{24}$ established a system which offered arbitration to patients as a way of resolving disputes arising from health care furnished by a physician, hospital, or other health care provider. ${ }^{25}$ The Act mandated that insured hospitals, HMO's, clinıcs, and sanatoria offer an Agreement to Arbitrate to patients. Further, the statute provided for the administration of arbitration proceedings "by the American Arbitration Association or other entity organized to arbitrate disputes pursuant to this chapter." 26 The statute also provides an optional arbitration mechanism for patients treated or examined in the office of a health care provider. ${ }^{27}$

The Act does not compel arbitration of all medical claims; arbitration is elective. Patients who believe they have a claim for medical negligence may seek arbitration or sue in court. The patient's election to arbitrate must be demonstrated by an Agreement to Arbitrate. If the agreement is not revoked by the patient or his legal representative, ${ }^{28}$ then the claim is appropriate for arbitration. The statute states that the agreement will expire one year after its execution but may be renewed. ${ }^{29}$

An impartial panel makes the determination of medical negligence and concomitant liability. The three-member panel consists of an attorney, who serves as the chairperson; a physician, hospital administrator or other health care licensee; and a member of the public. Panel members must be

\footnotetext{
${ }^{23}$ Jones, Medical Malpractice Insurance-An Update 81 (June 6, 1977).

241975 Мıсн. Pub. Acts Nos. 140, 141 (codified at MıсH. Comp. Laws $\$ \$ 00.3051$ $.3062,600.5033-.5065(1979))$.

${ }^{25}$ Mich. Comp. Laws $\$ 600.5041$ (1) (1979).

${ }^{26}$ МicH. Comp. Laws $\$ 600.5040(2)$ (a) (1979).

${ }^{27}$ Mich. Comp. Laws $\$ 600.5042(5)$ (1979).

${ }^{28}$ A patient may revoke an Agreement to Arbitrate within sixty days of being discharged from the hospital. Мıсн. Comp. Laws $\S \S 600.5041(3), 600.5042(3)$ (1979).

${ }^{29}$ Мıсн. Comp. Laws $\$ 600.5041$ (4) (1979).
} 
mutually agreed upon by the parties. ${ }^{30}$ A 1980 amendment to the Act established new procedures which included the substitution of a dentist for a physician in cases concerning alleged dental malpractice. ${ }^{31}$

The composition of the panel, specifically the inclusion of a medical specialist, and the manner in which arbitration is offered, i.e. within the hospital admission context, led to a myriad of constitutional and contractual challenges to the statute.

\section{THE LEGAL CHALLENGES TO THE MEDICAL MALPRACTICE ARBITRATION ACT}

Within months of its formal implementation, the Medical Malpractice Arbitration Act was beset with numerous constitutional and contractual challenges. The appeals court decisions addressing these challenges frequently differed as to the validity of the arbitration process for medical malpractice claims: ${ }^{32}$ The Michigan Supreme Court resolved these challenges in favor of the validity of the Medical Malpractice Arbitration Act on both constitutional and contractual issues in Morris v. Metriyakool. ${ }^{33}$ Before Morris, the constitutional and contractual challenges elicited conflicting judicial perspectives.

\section{A. The Constitutional Issues}

Plaintiffs challenging the validity of arbitration agreements have raised primarily two constitutional issues. First, they have claimed that the composition of the arbitration panel, specifically the inclusion of a medical specialist on the panel, violates their right to an impartial tribunal and thereby deprives them of due process. ${ }^{34}$ Additionally, they have argued

${ }^{30}$ Mich. Comp. Laws $\$ 600.5044(3)$ (1979).

${ }^{31} \mathrm{M}$ ICH. Comp. Laws $\$ 600.5044(2)$ (1979).

${ }^{32}$ The court of appeals in Michigan is an intermediate appellate court. It has statewide jurisdiction of those cases "appealed as of right." Eighteen judges comprise the court. Each judge is assigned to three-judge panels on a rotation basis. Judges for each panel are assigned by the Chief Judge of the Court of Appeals. Unanimous decisions are not required; a majority decision establishes a statewide precedent.

${ }^{33} 418$ Mich. 423,344 N.W.2d 736 (1984).

${ }^{34}$ See, e.g., Edwards v. St. Mary's Hosp., 120 Mich. App. 1, 327 N.W.2d 377 (1982); Ballard v. Southwest Detroit Hosp., 119 Mich. App. 814, 327 N.W.2d 370 (1982); Christman v. Sisters of Mercy Health Corp., 118 Mich. App. 719, 325 N.W.2d 801 (1982); Gale v. Providence Hosp., 118 Mich. App. 405, 325 N.W.2d 439 (1982); Cushman v. Frankel, 111 Mich. App. 604, 314 N.W.2d 705 (1981); Brown v. Considine, 108 Mich. App. 504, 310 N.W.2d 441 (1981); Brown v. Siang, 107 Mich. App. 91, 309 N.W.2d 575 (1981); see also Mengel, supra note 4. The Author contends that another issue can be discerned in these cases, making a fair case for what is known as "substantive due process." The Act violates due process because it abolishes a victim's common law right to sue in a civil court for a health care 
that the arbitration agreement impermissibly leads them to waive their right to a jury trial and that such a waiver should not be valid. ${ }^{35}$ While the panels of the court of appeals have offered conflicting opinions on these issues, the Michigan Supreme Court, in Morris, resolved these issues in favor of the Act's constitutionality and the validity of the agreements.

\section{Deprivation of Procedural Due Process}

Plaintiffs in malpractice disputes have argued that the presence of a medical specialist on the panel constitutes a bias toward the health care provider, thereby depriving the plaintiff of a fair and full hearing. ${ }^{36}$ They have contended that the fact that one member of a panel must be a doctor or hospital administrator "creates a situation in which 'the probability of actual bias on the part of the ... decisionmaker is too high to be constitutionally tolerable." "37 The panels of the court of appeals have responded differently to these arguments. In Morris $v$. Metriyakool, ${ }^{38}$ the appellate panel concluded that the Michigan Medical Arbitration Act was not unconstitutional since it did not deprive patients of a meaningful opportunity to decide whether to relinquish their constitutional right to "court access."39 The court said that the arbitration form adequately informs the patient that arbitration is a substitute for a trial by judge or jury. The court relied on the presumption that an election to arbitrate is voluntary and not the result of coercion. ${ }^{40}$

\footnotetext{
provider's negligent acts. However, to justify the existence of substantive due process, a party must demonstrate "either that there is no public purpose to be served by the statute, or that there is no reasonable relationship between the remedy adopted by the legislature and the public purpose." Mengel, supra note 4, at 325. The first portion of the legal equation can be overcome; the first part of this Article suggests that the malpractice crisis needed to be addressed by providing alternatives to litigation. Thus, the public purpose prong of the test is satisfied. Insofar as the second aspect is concerned, the remedy of the state legislature was to provide a method of dispute resolution which would expedite claims disposition, and confront the malpractice crisis. Arbitration was never intended to displace litigation but was designed as an alternative method for the plaintiff to pursue his remedy for tortuous negligent conduct. Still, it is questionable whether the second aspect of the test can be met.

${ }^{35}$ See, e.g., Moore v. Fragatos, 116 Mich. App. 179, 321 N.W.2d 781 (1982).

${ }^{36}$ See, e.g., Sabatini v. Marcuz, 122 Mich. App. 494, 332 N.W.2d 629 (1982); McKinstry v. Valley Obstetrics/Gynecology, 120 Mich. App. 479, 327 N.W.2d 507 (1982); Lovell v. Sisters of Mercy Health Corp., 119 Mich. App. 44, 325 N.W.2d 619 (1982); Horn v. Cooke, 118 Mich. App. 740, 325 N.W.2d 558 (1982); Murray v. Wilner, 118 Mich. App. 352, 325 N.W.2d 422 (1982); Malek v. Jayakar, 116 Mich. App. 111 , 321 N.W.2d 858 (1982); Rome v. Sinai Hosp., 112 Mich. App. 387, 316 N.W.2d 428 (1982); Piskorski v. Art Centre Hosp., 110 Mich. App. 22, 312 N.W.2d 160 (1981); Williams v. O'Connor, 108 Mich. App. 613,310 N.W.2d 825 (1981); Pipper v. Di Musto, 88 Mich. App. 743, 279 N.W.2d 534 (1979).

${ }^{37}$ Jackson v. Detroit Mem. Hosp., 110 Mich. App. 202, 204, 312 N.W.2d 212, 213 (1981), rev'd sub nom., Morris v. Metriyakool, 418 Mich. 423, 344 N.W.2d 736 (1984).

${ }^{38} 107$ Mich. App. 110, 309 N.W.2d 910 (1981), aff'd, 418 Mich. 423, 344 N.W.2d 736 (1984).

39 107 Mich. App. at 115, 309 N.W.2d at 911 .

$40 / d$.
} 
The appellate panel stated that the medical member of the arbitration board did not have a sufficient interest in the outcome of the malpractice award to disturb his impartiality. ${ }^{41}$ Without an indication of actual bias, and because the statutory procedure for the selection of the panel did not suggest a probability of systematic bias or prejudice, the requirements of due process were satisfied. ${ }^{42}$

The dissent in Morris arrived at different conclusions. ${ }^{43}$ After reviewing other decisions in which courts found an intolerable risk of bias, the dissent argued that

as the state-fostered arbitration system is currently structured it is inherently unlikely that any individual who agrees to arbitrate will understand the due process implications of this decision. The portion of the statute relating to the composition of the arbitration panels violates due process of law by forcing the litigant to submit his or her claim to a tribunal which is composed in such a way that a high probability exists that said tribunal will be biased against the claimant without mandating the use of an arbitration form explicitly detailing the nature of the panel's makeup. ${ }^{44}$

The dissent also considered the contention that the contract is unconscionable. The dissent acknowledged that "a declaration of unconscionability manifestly involves policy determinations" 45 and accordingly deferred to the policy set forth by the legislature as "policy-making is a legislative perogative." 46

Other panels of the appeals court did not reach the same conclusions as the Morris majority. In Jackson v. Detroit Memorial Hospital, ${ }^{47}$ the court adopted the position of the dissent in Morris and held the statute was unconstitutional for creating a risk of bias that was unacceptable. In Jackson, the plaintiff executed a standard Agreement to Arbitrate, and did not revoke the agreement during the sixty day period following her discharge. She subsequently instituted an action claiming that she was injured as a result of defendant's negligent treatment.

The plaintiff's primary argument was that the Michigan Medical Arbitration Act violated her due process right to a hearing before a fair and impartial tribunal by mandating that at least one member of the arbitration board be a physician or hospital administrator. ${ }^{48}$ The court, relying upon

\footnotetext{
${ }^{41}$ Id. at 120,309 N.W.2d at 913 .

${ }^{42} I d$.

${ }^{43} \mathrm{Id}$. at 121,309 N.W.2d at 913 (Bronson, J. concurring in part, dissenting in part).

${ }^{44}$ Id. at 134,309 N.W.2d at $919-20$.

${ }^{45} I d$. at $137-38,309$ N.W.2d at 921 .

${ }^{46} I d$.

${ }^{47}$ Jackson v. Detroit Mem. Hosp., 110 Mich. App. 202, 204, 312 N.W.2d 212, 213 (1981), rev'd sub nom., Morris v. Metriyakool, 418 Mich. 423, 344 N.W.2d 736 (1984).

${ }^{48}$ Id. at 204,312 N.W.2d at 213.
} 
the dissent in Morris, ${ }^{49}$ concluded that the statutorily prescribed composition of the arbitration panel created a situation in which the probability of decision-maker bias on the part of the panel was too high to be constitutionally tolerable. ${ }^{\mathbf{5 0}}$

Further, in Piskorski v. Art Centre Hospital, ${ }^{51}$ the court considered the conflicting opinions among the appellate judges and concluded that the reasoning in Jackson was the most compelling. The court also held that the Act was unconstitutional.

Subsequent decisions increasingly followed Jackson and the dissent in Morris and held that the statute was unconstitutional. Several judges changed their earlier opinions and concluded that the panel created a constitutionally impermissible risk of bias. In Strong v. Oakwood Hospital, ${ }^{\mathbf{5 2}}$ Judge Riley reversed her earlier position and held that "the composition of the panel and the failure to advise the patient of this fact are violative of his due process rights." 53

In Morris, the Michigan Supreme Court rejected the trend among the panels of the court of appeals, holding that the statute was not unconstitutional. ${ }^{54}$ The court looked for "a pecuniary interest which creates a probability of unfairness, a risk of actual bias which is too high to be constitutionally tolerable" 55 and held that such a risk was not demonstrated. The court acknowledged the relationship between the malpractice insurance awards and the cost of malpractice insurance, and recognized that health care providers will be affected by a decision by the malpractice panel. The court, however, held that this was insufficient to offend due process, saying " $[\mathrm{w}] \mathrm{e}$ have been shown no grounds for us to conclude that these decisionmakers will not act with honesty and integrity." 56

The supreme court properly rejected the trend among appeals courts and affirmed the Morris majority's opinion. The fact that one member of a panel must be a doctor or a hospital administrator does not necessarily deprive a patient of the right to a fair and impartial hearing. All doctors and hospital administrators are not biased in favor of other doctors or hospitals. The peculiar education and knowledge of persons in the medical field are irreplaceable on a medical malpractice arbitration board. Further, a doctor or hospital administrator occupies a minority position on the board. While a particular doctor or hospital administrator may make a prejudicial decision because of potential malpractice insurance premium

\footnotetext{
${ }^{49} I d$. at 204,312 N.W.2d at 214.

${ }^{50} \mathrm{Id}$.

51110 Mich. App. 22, 312 N.W.2d 160 (1981).

32118 Mich. App. 395, 325 N.W.2d 435 (1982).

${ }^{53} \mathrm{Id}$. at 399,325 N.W.2d at 437.

54418 Mich. at 423,344 N.W.2d at 739.

${ }^{\mathrm{s5}} \mathrm{Id}$. at 423,344 N.W.2d at 738 .

${ }^{56}$ Id.
} 
increases, this does not warrant the conclusion that all doctors and hospital administrators should thereby be disqualified from the board. The value of their service outweighs the potential cost, absent a showing of actual bias. The doctor or hospital administrator panel member does not have a direct pecuniary interest in the outcome of the arbitration, a requisite for finding that a party to an arbitration proceeding has been denied due process. Members of an arbitration panel who are doctors or hospital administrators do not, on the basis of their professional designations alone, create a biased panel. A patient is not denied due process by having his claim settled by an arbitration panel that includes a doctor or hospital administrator particularly when the arbitration agreements, as here, are entered into voluntarily.

\section{Right to Trial by Jury}

The panels of the court of appeals have rendered conflicting decisions on the issue of whether plaintiffs have been deprived of due process because they have waived their right to "judicial process" without being adequately informed as to the significance of the waiver of that right. ${ }^{57}$ Initially, appellate decisions addressing this issue uniformly dismissed this argument by holding that the language of the agreement clearly informed the patient that arbitration was a substitute for a trial by a jury. ${ }^{58}$ These decisions emphasized that an arbitration agreement in Michigan is presumed to be valid if certain procedural requirements are met. The statute requires that health care providers seeking to use an arbitration agreement distribute an informational brochure. ${ }^{59}$ The brochure states, in boldface type, that health care will be furnished irrespective of whether the agreement is executed. Additionally, the patient has the right to revoke the agreement within sixty days of execution by written notification to the hospital. ${ }^{60}$ Agreements which comply with these provisions are presumptively valid. The party challenging the validity of the agreement has the burden of demonstrating that the agreement is, in fact, invalid. The presumption of validity if the procedural requirements are met prevents the frustration of the entire legislative scheme.

Subsequent decisions by panels of the appeals court, however, concluded that access to the court system is a fundamental constitutional right

${ }^{57}$ Compare Moore v. Fragatos, 116 Mich. App. 179, 321 N.W.2d 781 (1982), with Morris v. Metriyakool, 107 Mich. App. 110, 309 N.W.2d 910 (1981), aff'd, 418 Mich. 423, 344 N.W.2d 736 (1984).

${ }^{58}$ See Williams v. O'Connor, 108 Mich. App. 613, 310 N.W.2d 825 (1981); Brown v. Siang, 107 Mich. App. 91, 309 N.W.2d 575 (1981); Morris, 107 Mich. App. 110, 309 N.W.2d 910 (1981). Albeit Judge Burns dissented in this case, his dissent was predicated upon the failure to designate the nature of the panel's composition in the arbitration agreement. This omission, he contended, was the quintessence of a knowing and voluntary waiver of the right to a jury trial.

${ }^{59}$ Mich. Сomp. Laws $\$ 600.5041$ (6) (1979).

${ }^{60} \mathrm{Id}$. 
and cannot be cavalierly waived. In Moore $v$. Fragatos, ${ }^{61}$ the appeals court stated that the arbitration agreement amounts to a waiver of a patient's constitutional right to a jury trial and such a waiver must be made knowingly, intelligently and voluntarily. ${ }^{62}$ The plaintiff had been admitted to a hospital for treatment by the defendant. Upon admission, he signed an agreement to arbitrate. The plaintiff claimed that he never read the papers; did not remember being informed of their nature; and thought that they were admittance papers and needed to be signed. The defendant contended that the agreement to arbitrate was valid and should be enforced.

The court held that the agreement to arbitrate caused the plaintiff to relinquish his constitutional right to a trial by jury and his right to access to the courts. Accordingly, the court set forth guidelines to examine whether this waiver was made knowingly, intelligently and voluntarily. For a waiver to be knowing, the court said that the "record must affirmatively show that the plaintiff was aware that he was signing an arbitration agreement." ${ }^{\prime \prime 3}$ The court held that the presumption against a waiver of a constitutional right was greater than the presumption that "a person has read what he has signed." 64 Accordingly, the court required additional evidence to demonstrate that the waiver was knowing.

The court also held that the waiver must be intelligent. The court said

[i]n order to make an intelligent choice, a person must be informed of the consequences of his decision: i.e., the material differences between malpractice arbitration and trial in civil court. 'material' information, in our view, is information that a reasonable person would consider important in deciding whether or not to sign an arbitration agreement. ${ }^{65}$

The court held that a party

seeking to assert the waiver of a patient's right to access to the courts must affirmatively show that the patient was informed (1) that by signing the form, he would be giving up his right to trial by jury or a judge, (2) that the arbitration panel that would decide his case would include an attorney, a layman, and a doctor or hospital administrator, and (3) that doctors and hospital administrators on arbitration panels may have an incentive to minimize the number and size of malpractice awards, because their malpractice insurance rates are directly affected by those awards. ${ }^{66}$

\footnotetext{
${ }^{6} 116$ Mich. App. 179, 321 N.W.2d 781 (1982).

${ }^{62} I d$. at 186,321 N.W. $2 \mathrm{~d}$ at 785.

${ }^{63} I d$. at 188,321 N.W. $2 \mathrm{~d}$ at 786 .

${ }^{64} I d$. at 187,321 N.W. $2 \mathrm{~d}$ at 786 .

${ }^{65} I d$. at 189,321 N.W. $2 \mathrm{~d}$ at 786 .

${ }^{66} I d$. at 194,321 N.W. $2 \mathrm{~d}$ at 789.
} 
Finally, the court required that a patient must waive his constitutional right voluntarily. The court reviewed the "coerciveness inherent in the physician-patient relationship," and said

that a party seeking to assert the waiver of a patient's right to access to the courts must affirmatively show that the patient was informed (1) that he did not have to sign the arbitration agreement, (2) that the patient would receive the same quality of medical treatment and would be attended to just as quickly whether or not he chose to sign the agreement, (3) that doctors and hospitals are not permitted to refuse treatment to patients who do not sign the agreement, and (4) that signing the agreement is entirely up to the patient. ${ }^{67}$

The court did not find that the statute was unconstitutional or that the agreement was unconscionable. It held that a party seeking to uphold an arbitration agreement must present sufficient evidence to demonstrate that the patient knowingly, intelligently and voluntarily chose to relinquish his constitutional right to access to the courts.

The court recognized that while the jury trial is fundamental to the system of American jurisprudence, a person is entitled to select the forum and tribunal in which a malpractice dispute should be resolved. In essence, an individual possesses this right and can voluntarily relinquish it only after he has been given all the salient information. Although some commentators have treated this perfunctory assessment of the court of appeals as incongruous with the high esteem in which the right has always been held by Western jurisprudence, ${ }^{68}$ their analysis avoids the real issue: whether an unrestrained election to pursue arbitration of malpractice claims deprives the patient of meaningful access to a hearing. To assume that the average patient does not understand the implications of his or her execution of an arbitration agreement suggests that the law should immunize these people from the improvidence of their actions.

The legislative goal in designing the Act was to provide an alternative forum for the resolution of malpractice disputes. The arbitration mechanism is not an inferior adjudicatory process but a process which functions with equivalent procedural and substantive safeguards to ensure that due process is maintained.

\section{B. The Contractual Issues}

\section{Unconscionability and Adhesion Contracts}

As a method of dispute resolution, arbitration is based on freedom to

${ }^{67} I d$. at 197,321 N.W.2d at 790 .

${ }^{68}$ See Mengel, supra note 4. 
contract principles. ${ }^{69}$ Courts will generally uphold arbitration agreements because of their voluntary nature.$^{70} \mathrm{~A}$ court will not enforce an arbitration agreement if it finds that it is an unconscionable contract. ${ }^{71}$

Section 2-302 of the Uniform Commercial Code governs unconscionability. ${ }^{72}$ This section contains a number of criteria which signal unconscionsability, including fraud, illegality, warranty liability and the tort of misrepresentation. A panel of the Michigan appeals court said "[u]nconscionability has generally been recognized to include an absence of a meaningful choice on the part of one of the parties together with contract terms which are unreasonably favorable to the other party." 73

Unconscionability is often confused with, but is distinct from, the concept of an adhesion contract. The typical adhesion contract consists of a standard form drafted by a party who possesses strong bargaining power and offered to a party who possesses less or no bargaining power. The weaker party has no choice but to accept the terms of the contract, as changes cannot be negiotiated. The weaker party is virtually coerced into execution because the stronger party is the only party who can provide the goods or service, thus coercion is masked by "voluntary" consent. ${ }^{74}$ While unequal bargaining power is the primary factor in determining an adhesion contract, it is only part of the consideration in determining if a contract is unconscionable.

Plaintiffs opposing arbitration agreements have argued that the agreements were both adhesion contracts and unconscionable contracts. 1980).

${ }^{69}$ See S. Williston, A Treatise on the Law of Contracts $\$ 1023$ (3d ed. 1961 \& Supp.

70 See, e.g., Detroit Automobile Inter-Insurance Exchange v. Gavin, 416 Mich. 407, 331 N.W.2d 143 (1982); Bricklayers and Stone Masons Union, Local No. 2 v. NLRB, 562 F.2d 775 (D.C. Cir. 1977). See generally S. WiLListon, supra note 69, at $\$ 1721$.

${ }^{7}$ See, e.g., Lovell v. Sisters of Mercy Health Corp., 119 Mich. App. 44, 325 N.W.2d 619 (1982); Ballard v. Southwest Detroit Hosp., 119 Mich. App. 814, 327 N.W.2d 370 (1982). See generally S. WiLListon, supra note 69 , at $\$ 1763 \mathrm{~A}$.

${ }^{72}$ See Sisters of Mercy Health Corp., 119 Mich. App. at 44, 325 N.W.2d at 619 (1982). All states but three have now adopted UCC $\S 2-302$ which reads as follows:

1. If the court as a matter of law finds the contract or any clause of the contract to have been unconscionable at the time it was made, the court may refuse to enforce the contract, or it may enforce the remainder of the contract without the unconscionable clause, or it may so limit the application of any unconscionable clause as to avoid any unconscionable result.

2. When it is claimed or appears to the court that the contract or any clause thereof may be unconscionable the parties shall be afforded a reasonable opportunity to present evidence as to its commercial setting, purpose and effect to aid the court in making the determination.

${ }^{73}$ Strong, 118 Mich. App. at 400-01, 325 N.W.2d at 438 (quoting Williams v. WalkerThomas Furniture Co., 350 F.2d 445 (D.C. Cir. 1965)).

${ }^{74}$ Id. 
The panels of the court of appeals have consistently held that the arbitration agreements were not adhesion contracts ${ }^{75}$ because they were not preconditions to receiving health care and because patients could revoke them within sixty days of being discharged from the hospital. ${ }^{76}$

In contrast with the consistency of the courts on the adhesion contract issue, panels of the court of appeals have differed on whether the arbitration agreement constituted an unconscionable contract. In Strong v. Oakwood, ${ }^{77}$ the court found that the arbitration agreement was "unreasonable due to the lack of information presented to the patient such that a person of common sense who was aware of the deficiencies would not sign the agreement"78 and consequently unconscionable. The court listed some of the deficiencies it found with the contract:

The form which is signed fails to advise the patient of the composition of the panel. The agreement does not explain the truncated appellate process available after the arbitration... The form does not advise the patient or his family what procedures should be taken to revoke the agreement should the patient die while in the hospital or shortly after discharge from it. Furthermore, the agreement does not adequately explain the range of actions covered by the agreement. ${ }^{79}$

In Morris, the supreme court rejected these arguments and held that the arbitration agreement was not unconscionable. Since arbitration was the primary purpose of the agreement, the court said that "we do not believe that an ordinary person signing this agreement to arbitrate would reasonably expect a jury trial." 80

\section{Right to Revocation}

The Medical Malpractice Arbitration Act provides that the patient or his legal representative may revoke an Agreement to Arbitrate within sixty days of signing. ${ }^{81}$ However, the Agreement is binding upon the health care provider, granting no revocation or termination option. ${ }^{82}$

Plaintiffs seeking to avoid an arbitration agreement and defendants who would like to have the courts enforce an agreement have litigated issues surrounding the validity and timeliness of a revocation of the agree-

\footnotetext{
${ }^{75}$ See, e.g., Morris, 107 Mich. App. at 110, 309 N.W.2d at 910.

${ }^{76}$ See id.; see also Gale, 118 Mich. App. 405, 325 N.W.2d 439 (1982).

77118 Mich. App. 395, 325 N.W.2d 435 (1982).

${ }^{78}$ ld. at 402,325 N.W.2d at 437.

${ }^{79}$ Id. at $402-03,325$ N.W.2d at 438.

${ }^{80} 418$ Mich. at 423,344 N.W.2d at 739.

$81 \mathrm{Mich}$. Сомp. Laws $\$ 600.5041$ (3) (1979).

${ }^{82}$ Id.
} 
ment. For example, in Amwake v. Mercy Hospital, ${ }^{83}$ the plaintiff was comatose following an operation and was then transferred from the defendant hospital to another hospital. The court rejected the defendant's contentions that the agreement was not validly revoked and held that the revocation was valid under any of three theories. First, the court said that the filing of a complaint would serve to impliedly revoke an arbitration agreement. Second, the court said that the transfer from one hospital to another did not constitute a discharge, otherwise, "hospitals could shuttle patients from one hospital to another to start the 60-day period." ${ }^{4}$ Finally, the court analogized the patient's comatose condition to other disabilities and held that the sixty day period should begin at the time the disability is removed, in other words, at the time the patient or legal representative could revoke the agreement. ${ }^{85}$

A patient's ability to revoke an arbitration agreement was enhanced in Boiko v. Henry Ford Hospital. ${ }^{86}$ In Boiko, the plaintiff had died in the hospital, and was therefore never "discharged." The court rejected the plaintiff's arguments that the sixty day period should never commence as the patient was never discharged. The court sought to interpret the statute as a whole, and relied on the provision that the agreements should apply to all instances of medical malpractice, including those that cause death. The court resisted the temptation to equate death with the term "discharge" and held that the sixty day period began when a legal representative was appointed. By so holding, the legal representative would have the benefit of the full sixty days in accordance with the legislative policy expressed in the statute. ${ }^{87}$

Further, in DiPonio v. Henry Ford Hospital, ${ }^{88}$ the court held that the sixty day revocation period should not begin for a patient who dies in the hospital until a personal representative is appointed or the personal representative discovers or should discover the arbitration agreement. Relying on Amwake, the court arrived at the same conclusion as the Boiko court. In addition, the DiPonio court would allow additional time for a personal representative who did not know and would not have known about the arbitration agreement. The court adopted the reasoning of the "discovery rule" in tort law where the statute of limitations does not commence until the victim discovers or should discover the injury. ${ }^{89}$

The courts have been willing to extend the sixty day revocation period by analogizing to circumstances involving other statutes of limitations.

\footnotetext{
${ }^{83} 92$ Mich. App. 546, 285 N.W.2d 369 (1979).

${ }^{84} I d$. at 552,285 N.W.2d at 372.

${ }^{85}$ Id. at 553-54, 285 N.W.2d at $372-73$.

${ }^{86} 110$ Mich. App. 514,313 N.W.2d 344 (1981).

${ }^{87}$ Id. at 520,313 N.W.2d at $346-47$.

${ }^{88} 109$ Mich. App. 243, 311 N.W.2d 754 (1981).

${ }^{89} \mathrm{Id}$. at $250,252-53,311 \mathrm{~N} . \mathrm{W} .2 \mathrm{~d}$ at $737-38$.
} 
These extensions protect patients' constitutional rights and effectuate the legislature's policy as expressed in the statute.

\section{EVALUATION AND EXPERIENCE UNDER THE MICHIGAN MEDICAL ARBITRATION PROGRAM}

As with any new modality, the Medical Malpractice Arbitration Act sparked significant interest in assessing the impact of arbitration on the management of medical malpractice disputes in Michigan. The statute required that an assessment of the malpractice arbitration mode occur within three years of its implementation. ${ }^{90}$ In 1982, Applied Social Research, Inc., (ASR) an Oregon based firm, assumed contractual responsibilities for the evaluation. Preliminary reports began to be released in August of 1983 .

ASR issued its final report in October, 1983, including six detailed surveys of claims incidents, arbitration, patients' perspective, the hospital personnel and insurance company chief executive's perspectives. ${ }^{91}$ The evaluation examined various dimensions, including time limits, costs, predictability, access and fairness/justice. The report made recommendations to aid in curing the "perceived" defects of the arbitration process.

\section{A. Validity of Signed Arbitration Agreements}

The report stated that given the concern that patients may or may not be sufficiently informed when they execute an arbitration agreement, a more formal presentation or indoctrination concerning the aspects of arbitration should be made at the time the patient is presented with the agreement. ${ }^{92}$ To accomplish this, the report proposed several modifications. The report suggested that a physician should assume responsibility for the accurate presentation of the arbitration agreement to patients in his office. ${ }^{93}$ In the hospital, the staff should present the arbitration agreement to patients as a distinct event so it is not simply an additional form to execute. In addition, the staff who present the arbitration agreement to patients should fully understand the arbitration program and have sufficient time to present clearly the options to patients. ${ }^{94}$ The report suggested that an arbitration agreement may be altered to secure an affirmative declaration from the patients, but in this context, all changes must be initiated by the patient and he must sign the agreement, indicating

90 Мich. Сomp. Laws $\$ 600.5065$ (1979).

91 Applied Social Research, Inc., Evaluation, State of Michigan Medical Malpractice Arbitration Program Summary Report (1983).

92 Id. at $32-34$.

${ }^{93} \mathrm{Id}$. at 33 .

${ }^{94} I d$. 
that he understands the program. In particular, the patient should understand that signing the arbitration agreement is not a prerequisite of the receipt of care or treatment; that the panel is composed of an attorney, a health care provider, and a lay citizen; that in signing the arbitration agreement, he is choosing to resolve any medical malpractice dispute by arbitration rather than in the courts; that there is a revocation procedure available, and the patient should understand that the arbitration option is generally deemed final and binding except in rare circumstances. ${ }^{95}$ Appellate review of arbitration is narrow, and the Medical Malpractice Arbitration Program was designed to be consistent with the general arbitration procedures.

\section{B. Arbitration Panel Composition}

The evaluation results indicated that there was no basis for any presumption of bias on the part of any panel member of the arbitration panel, including the health care provider. However, in response to proposals to remove the doctor or hospital administrator from the panel, the report concluded that there was no reason to believe that the performance of the arbitration system would be "adversely affected by a change in panel composition." 96

\section{Outpatient and Emergency Room Arbitration Offering}

A more cautious presentation of the arbitration agreement must be made to patients in emergency room and outpatient setting. Given the substantial burden placed on hospital administrators under circumstances unique to both emergency room and outpatient settings, the arbitration program should be modified to allow hospitals to use their discretion insofar as offering or not offering the arbitration agreement. ${ }^{97}$

${ }^{95} \mathrm{Id}$. at 34 .

${ }^{96} I d$. at 40 . The system of utilizing professionals rather than peers was to insure that histrionics and emotional soliloquies by skilled advocates would be displaced by a cautious and informed weighing of the evidence. By being impervious to these especial machinations, the expectation is that the disposition of malpractice claims in arbitration are more representative of the plaintiff's actual injuries. In some measure, arbitration can be deemed "protectionist" by both the consumer of health care services and the medical profession. Of the 419 cases initiated between 1976 and February 29, 1984, 86 resulted in awards. There was a unanimous ruling in all but one of these decisions. Although the plaintiffs' advocates contend that the inclusion of medical specialists on the panel favors physicians and protects health care providers, the statistical information supports a contrary conclusion. The arbitration panel is required, as are judges and juries, to follow established legal precepts and standards in determining fault.

${ }^{97}$ Id. at $41-42$. 


\section{Continuation of the Medical Malpractice Arbitration}

To maximize the benefits of arbitration, a significant majority of health care providers must support the Medical Malpractice Arbitration Program. Statutory authorization for the program should be assigned to the Division of Health Facilities, Licensing and Certification, Department of Public Health. ${ }^{98}$

The major obstacle toward achieving a thorough and balanced report on the arbitration process was Applied Social Research, Inc.'s failure to secure comparable statistics from the court systems in Michigan. Therefore, the empirical results of the survey should be viewed with caution and circumspection.

Nevertheless, given the general recommendations of the Report, it would behoove the members of the legal and medical professions to proselytize the benefits of arbitration to the health care consuming public and to insure its continuance. These benefits include an expeditious, creative, and more humane resolution of medical malpractice claims. ${ }^{99}$

\section{CONCLUSION}

The Michigan Medical Malpractice Arbitration Act was the Michigan legislature's response to the growing malpractice crisis. It provided an alternative mechanism for the resolution of disputes that arise during the course of providing medical care. Despite constitutional and contractual challenges to the arbitration system, the Michigan Supreme Court approved the legislature's arbitration system. Other states that look for possible solutions to the malpractice crisis should review Michigan's experience under its statute.

Currently, legal scholars continue to debate the relative merits of Michigan's medical arbitration scheme. Does it dilute the penumbra of procedural and substantive rights to which a plaintiff is entitled? Does it deprive the patient of a meaningful choice of forum because the environment in which the Agreement to Arbitrate is offered allegedly threatens subtly the patient's emotional stability? Should the program be replaced by peer screening committees, members of which can, due to professed expertise, resolve disputes more effectively and efficiently? Will the program, if permitted to continue, assist in lessening the malpractice crisis?

While the supreme court decided these issues in favor of the constitu-

98 Id. at 43 .

${ }^{99}$ Although the ASR survey of arbitration disclosed that dispositions in arbitration take two months less than dispositions in a court, it is recognized that this situation is, by and large, a consequence of the legal battles being waged. Now that the constitutional challenges have been resolved, the cases should progress more rapidly. 
tionality and validity of the arbitration process in Morris, observers will continue to question whether arbitration panels are impartial and whether a patient makes a voluntary, knowing, and intelligent waiver of a constitutional right when he signs an Agreement to Arbitrate. The need for a better understanding of the arbitration process in a malpractice setting continues. The arbitration process was not intended to be a panacea for the crisis enveloping the medical profession in the 1970's. It was designed and promoted as a viable and humane alternative to the "litigation explosion."

In addressing the members of the legal profession at the ABA meeting in Las Vegas in February of 1984, Chief Justice Burger observed that we have become "mesmerized by the rule of law ...." He continued to note:

Our distant forebearers moved slowly from trial by battle and other barbaric means of solving conflicts and disputes, and we must move away from total reliance on the adversary contest resolving all disputes. For some disputes, trials will be the only means, but for many claims, trials by the adversarial contest must in time go the way of the ancient trial by battle and blood. Our system is too costly, too painful, too destructive, too inefficient for a truly civilized people. To rely on the adversarial process as the principle means of resolving conflicting claims is a mistake that must be corrected. ${ }^{100}$

A close look at the process and its operational facets should yield the recognition that the drafters of the legislation have realized, albeit in part, the satisfaction of their objectives. Its survival will not be a Phyrric victory for its proponents, nor a resounding defeat for its opponents. The legislative enactments of 1975 were intended to extend equity, justice and law beyond the formalistic parameters of the courtroom. Polemics can no more be defeasible in legal jurisprudence than in arbitral jurisprudence. Neither system professes superiority; both possess attributes. Sophisticated commentators and jurists will regard malpractice arbitration in this light.

${ }^{100}$ Address by Chief Justice Burger, American Bar Association convention, in Las Vegas (Feb. 1984). 


\title{
AMERICAN JOURNAL OF LAW \& MEDICINE
}

VOLUME 10 NUMBER 3 FALL 1984

\section{BOSTON UNIVERSITY SCHOOL OF LAW STUDENT BOARD OF EDITORS}

\author{
EDITOR-IN-CHIEF \\ Nathan Gibson \\ EXECUTIVE EDITOR \\ Jeri Zeder \\ MANAGING EDITOR \\ Theodore Winokur

\section{PROJECTS EDITOR} \\ Jay S. Geller \\ Kirk Burns \\ Thomas A. Cohn \\ Kelly Copeland \\ Jeffrey Herz \\ Peter Kenyon \\ Laura D. Kreel \\ John E. Arbab \\ Michael A. Berkowitz \\ William A. Bogdan \\ Brian A. Bosch \\ Lincoln W. Briggs \\ James D. Burton \\ Catherine M. Butler \\ Tim G. Caron \\ Gregory D. Chafee \\ Elizabeth Cohen \\ Donna DeSisto \\ Kevin Donnelly \\ Stephen C. Filler \\ CASE \& NOTE EDITORS \\ Edward M. Fox \\ Michael E. Katzenstein \\ Mitchell Katzman \\ David R. Kraus \\ Paul Thomas \\ Melissa Zelen

\section{ASSOCIATE EDITORS} \\ Tina Liebling \\ Steven V. Napolitano \\ Deborah Novick \\ Mark Ollman \\ Robyn Reiken \\ Helen A. Salichs

\section{MEMBERS} \\ Edward Gelles \\ Steven M. Golub \\ Jennifer E. Goodnow \\ Linda S. Gorby \\ Eric J. Gouvin \\ Cynthia J. Greco \\ Mark S. Gregory \\ Ellen M. Holtzman \\ Joe Jacobson \\ Gary S. Kessler \\ Paul Kleinman \\ Robert J. Knisley \\ David M. Levine

\section{ARTICLES EDITORS} \\ Steven Curwin \\ Judith $\mathrm{H}$. Itkin \\ Thomas E. Scribner \\ Susan F. Scharf \\ Carin Sigel \\ Richard Sobel \\ Michael Trager \\ Chet Waldman \\ Alice Warner \\ Elaine R. Wohlmuth \\ Laurence Moelis
Anne M. Murphy
Lynn E. Norman
Fred Plevin
Frederic G. Pratt
Roz Rowen
Joseph D. Simon
Michele Stolls
Ellen M. Tepperman
Bruce D. Todesco
Robert T. Treat
Douglas P. Warner
Abby B. Wayne
Denise D. Wilson
}

\section{PUBLICATIONS ASSISTANT}

Tobi D. Wiseman

\author{
FACULTY ADVISOR \\ Frances H. Miller
}


HeinOnline -- 10 Am. J.L. \& Med. 308 1984-1985 